\title{
Biodiversity of Spongosorites coralliophaga (Stephens, 1915) on coral rubble at two contrasting cold-water coral reef settings
}

\author{
Georgios Kazanidis $^{1}$ - Lea-Anne Henry ${ }^{2} \cdot$ J. Murray Roberts $^{2,3,4} \cdot$ Ursula F. M. Witte $^{1}$
}

Received: 10 November 2014 / Accepted: 14 September 2015/Published online: 22 October 2015

(C) The Author(s) 2015. This article is published with open access at Springerlink.com

\begin{abstract}
Cold-water coral reefs (CWRs) in the northeast Atlantic harbor diverse sponge communities. Knowledge of deep-sea sponge ecology is limited and this leaves us with a fragmented understanding of the ecological roles that sponges play in CWR ecosystems. We present the first study of faunal biodiversity associated with the massive demosponge Spongosorites coralliophaga (Stephens, 1915) that typically colonizes coral debris fields of CWRs. Our study focused on the sessile fauna inhabiting sponges mixed with coral rubble at two contrasting settings in the northeast Atlantic: the shallow inshore (120-190 m water depth) Mingulay Reef Complex (MRC) and the deep offshore (500-1200 m) Logachev Mound (LM) coral province. MRC is dominated by the scleractinian Lophelia pertusa, while LM is dominated by $L$. pertusa and Madrepora oculata. Nine sponge-coral rubble associations were collected from MRC and four from LM. Measurements of abundance, species richness, diversity, evenness, dry biomass, and composition of sessile fauna on sponge and coral rubble microhabitats were undertaken. Differences in community composition between the two
\end{abstract}

Communicated by Biology Editor Prof. Brian Helmuth

Georgios Kazanidis

r02gk11@abdn.ac.uk

1 Oceanlab, School of Biological Sciences, University of Aberdeen, Aberdeen AB41 6AA, UK

2 Centre for Marine Biodiversity and Biotechnology, School of Life Sciences, Heriot-Watt University, Edinburgh EH14 4AS, UK

3 Center for Marine Science, University of North Carolina Wilmington, $601 \mathrm{~S}$. College Road, Wilmington, NC 28403-5928, USA

4 Scottish Association for Marine Science, Scottish Marine Institute, Oban, Argyll PA37 1QA, UK regions were mainly a response to changes in fauna with depth. Fauna composition was also different between sponge and coral rubble within each region. Infauna constituted a minor component of the sponge-associated fauna in MRC but had a higher contribution in LM. Sponge and coral rubble sessile fauna in both regions was mainly composed of cnidarians and molluscs, similarly to some previous studies. Sponges' outer surfaces at MRC were colonized by a speciesrich community with high abundance and biomass suggesting that $S$. coralliophaga at MRC acts as a settlement surface for various organisms but such a role is not the case at LM. This difference in the role of $S$. coralliophaga as a biological structure is probably related to differences in fauna composition with depth, bottom current speed, and the quantity/ quality of food supplied to the benthos.

Keywords Porifera $\cdot$ Symbionts $\cdot$ Microhabitats · Biodiversity

\section{Introduction}

Sponges (Phylum Porifera) constitute a highly diverse faunal group that create ecologically significant biological structures (Buhl-Mortensen et al. 2010; Hogg et al. 2010) as they supply substrate for attachment, food particles, and shelter from predation to various epifaunal organisms (Bell 2008 and references therein; Wulff 2012 and references therein). Recent evidence has shown that shallow-water sponges may play a key role in reef food webs through their ability to convert dissolved to particulate organic matter which is subsequently made available to reef fauna, thus enabling hot spots of diversity and biomass to persist in oligotrophic environments (de Goeij et al. 2013). In addition, sponges harbor diverse microbial communities 
which are involved in a number of nitrogen-processing pathways such as nitrification, nitrogen fixation, denitrification, and anammox (Fiore et al. 2010 and references therein; Ribes et al. 2012; Han et al. 2013); however, due to the complexity of these processes (e.g., Hoffmann et al. 2009), our knowledge of the role of sponges in nitrogen cycling at local, regional, or global scale remains very limited (Maldonado et al. 2012).

In comparison with shallow-water ecosystems, knowledge of the physiology and ecology of deep-sea sponges is still very limited (Witte and Graf 1996; Witte et al. 1997; Pile and Young 2006; Yahel et al. 2007), as is knowledge of their role as biological structures (Klitgaard 1995; Beaulieu 2001; Buhl-Mortensen et al. 2010). This hampers our understanding of the deep-sea ecosystem functions provided by sponge habitats. In the cold-water coral reefs (CWRs) of the northeast Atlantic Ocean, recent studies have described a diverse community of associated sponges (van Soest and Lavaleye 2005; van Soest et al. 2007; Roberts et al. 2009). CWRs are themselves ecosystems with high ecological and economic values, and they are very sensitive to anthropogenic disturbance (Roberts et al. 2009; Henry et al. 2013b); thus, knowledge of their structure and function is a prerequisite for the implementation of efficient management strategies (Henry et al. 2013a).

The present study investigates the fauna living in association with the demosponge $S$. coralliophaga (Stephens, 1915) and its underlying coral rubble at two CWRs of the northeast Atlantic, aiming to provide a first insight into the contribution of this species to the structure of the reef and especially to habitat complexity and biodiversity. $S$. coralliophaga is abundant in CWRs and is characterized by its massive body form and extensive colonization of coral rubble (van Soest et al. 2007; Vad 2013).

\section{Materials and methods}

\section{Collection of samples}

Specimens of the sponge $S$. coralliophaga that had colonized coral rubble and the associated fauna were collected by the remotely operated vehicle (ROV) Holland I in two contrasting settings, Mingulay Reef Complex (MRC) and Logachev Mounds (LM), in May/June 2012 during the Changing Oceans 2012 expedition on board the Royal Research Ship (RRS) James Cook (JC073 cruise; Roberts and shipboard party 2013; Table 1; Fig. 1). S. coralliophaga, being large in size and yellow in color (Fig. 2), was easily identified during ROV surveys. After its collection from the seafloor using the ROV manipulator arm, the sponge-coral rubble association was carefully transferred
Table 1 Locations of sample collection at Mingulay Reef Complex (MRC) and Logachev Mound (LM)

\begin{tabular}{llll}
\hline Location & Depth $(\mathrm{m})$ & Latitude & Longitude \\
\hline MRC & 127 & $56^{\circ} 49.3^{\prime} \mathrm{N}$ & $7^{\circ} 23.6^{\prime} \mathrm{W}$ \\
& 128 & $56^{\circ} 49.3^{\prime} \mathrm{N}$ & $7^{\circ} 23.6^{\prime} \mathrm{W}$ \\
& 127 & $56^{\circ} 49.3^{\prime} \mathrm{N}$ & $7^{\circ} 23.6^{\prime} \mathrm{W}$ \\
& 131 & $56^{\circ} 49.3^{\prime} \mathrm{N}$ & $7^{\circ} 23.7^{\prime} \mathrm{W}$ \\
& 122 & $56^{\circ} 49.3^{\prime} \mathrm{N}$ & $7^{\circ} 23.6^{\prime} \mathrm{W}$ \\
& 128 & $56^{\circ} 49.3^{\prime} \mathrm{N}$ & $7^{\circ} 23.6^{\prime} \mathrm{W}$ \\
& 128 & $56^{\circ} 49.3^{\prime} \mathrm{N}$ & $7^{\circ} 23.6^{\prime} \mathrm{W}$ \\
& 131 & $56^{\circ} 49.3^{\prime} \mathrm{N}$ & $7^{\circ} 23.6^{\prime} \mathrm{W}$ \\
& 131 & $56^{\circ} 49.3^{\prime} \mathrm{N}$ & $7^{\circ} 23.6^{\prime} \mathrm{W}$ \\
LM & 800 & $55^{\circ} 29.6^{\prime} \mathrm{N}$ & $15^{\circ} 49.2^{\prime} \mathrm{W}$ \\
& 683 & $55^{\circ} 29.6^{\prime} \mathrm{N}$ & $15^{\circ} 49.1^{\prime} \mathrm{W}$ \\
& 683 & $55^{\circ} 29.6^{\prime} \mathrm{N}$ & $15^{\circ} 49.1^{\prime} \mathrm{W}$ \\
& 683 & $55^{\circ} 29.6^{\prime} \mathrm{N}$ & $15^{\circ} 49.1^{\prime} \mathrm{W}$ \\
\hline
\end{tabular}

to the ROV biobox, a storage compartment that closes once withdrawn beneath the vehicle and during recovery to the surface.

The MRC in the Outer Hebrides Sea comprises live coral reef areas at 120-190 m depth, dominated by the scleractinian Lophelia pertusa (Roberts et al. 2005, 2009). Hydrographic surveys have revealed a south-southwest (SSW) to north-northeast (NNE) direction in major surface and seabed flows, as well as the importance of rapid downwelling of surface water and advection of deep bottom water as mechanisms of food supply for the reef communities (Davies et al. 2009; Roberts et al. 2009; Duineveld et al. 2012; Findlay et al. 2014; Moreno Navas et al. 2014). In the MRC area, hydrographic and bathymetric variables have been predicted to be responsible for community variation across broader spatial scales while recruitment, intra- and interspecific social interactions, and food supply seem to play a greater role in the fine-scale assembly of communities (Henry et al. 2010, 2013a).

In contrast to the shallow inshore setting of the MRC, the LM are large offshore carbonate mounds situated on the southeast Rockall Bank (500-1200 m depth; van Weering et al. 2003) dominated by L. pertusa and Madrepora oculata (van Weering et al. 2003; Duineveld et al. 2007). Hydrographic studies in the area have demonstrated the importance of advection in sustaining the food supply to the LM reef community (Duineveld et al. 2007), with recent modeling studies highlighting the importance of coral carbonate mound structure in promoting local vertical mixing and organic matter flux to the benthos (Mohn et al. 2014).

Nine $S$. coralliophaga-coral rubble samples were collected at MRC and four at LM (Table 1; Fig. 2a-e). 
Fig. 1 Sites of sample collection. Mingulay Reef Complex (MRC) and Logachev Mound (LM)

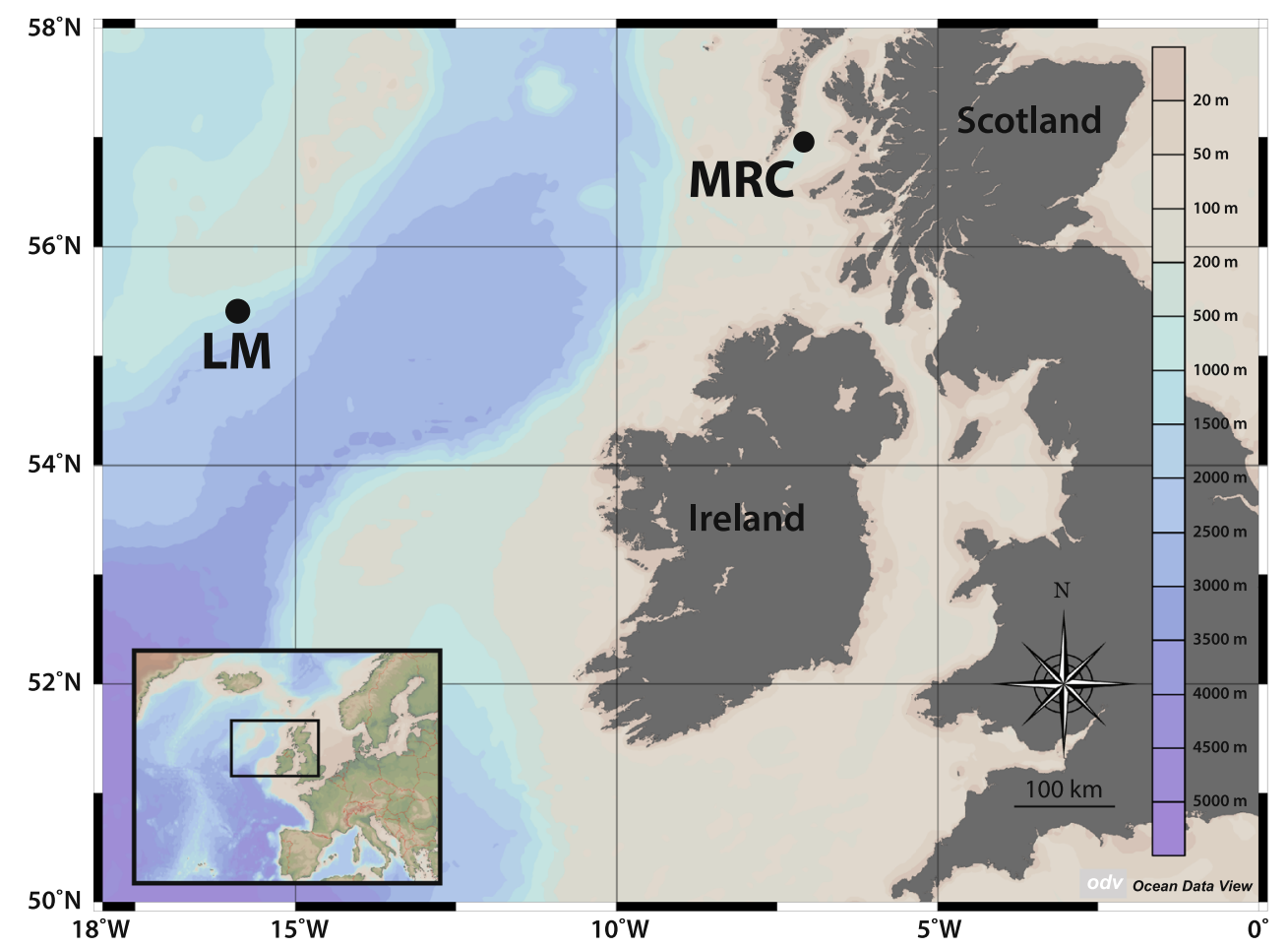

Immediately after collection by the ROV, these samples were fixed in $10 \%$ seawater formalin.

\section{Sample processing}

In the laboratory, the sponge-coral rubble associations were initially examined for the presence of fauna: (1) on outer sponge surface; (2) on coral rubble; and (3) on secondary biogenic structures (i.e., species living on the outer sponge surface/coral rubble and which were later colonized by other epifaunal organisms). Thereafter, sponges were carefully dissected with a scalpel and the internal structures (i.e., canals, cavities) were examined for the presence of infaunal organisms. All specimens collected were identified to the lowest possible taxonomic level with help from specialists, and the number of individuals from each association was recorded. Furthermore, the individuals from each association were dried at $60{ }^{\circ} \mathrm{C}$ for $48 \mathrm{~h}$ before their dry weight was recorded $( \pm 0.01 \mathrm{mg})$. In addition, the volume of dried sponge $\left(60{ }^{\circ} \mathrm{C}, 48 \mathrm{~h}\right)$ and the volume of coral rubble were measured through the water displacement method ( $\pm 1 \mathrm{~cm}^{3}$; Ribeiro et al. 2003; Fiore and Jutte 2010).

Only living specimens were taken into account in the numerical/statistical analyses described below. Each species of the sessile fauna was assigned to one (or both) of the two microhabitats-S. coralliophaga and/or coral rubble. Sponge infauna was assigned to the $S$. coralliophaga microhabitat. The individuals that were found on secondary biological structures were incorporated accordingly (e.g., foraminiferans that had colonized hydroids living on outer sponge surface were grouped into the $S$. coralliophaga microhabitat). Specimens of mobile fauna (see Table 2 for details) were not assigned to microhabitats and thus were not taken into account in the comparisons between sponge and coral rubble. Allocation of the sessile fauna and sponge infauna to microhabitats was used to group samples a priori as follows: (1) MRC sponge, (2) MRC coral rubble, (3) LM sponge, and (4) LM coral rubble. In addition to a microhabitat, each species of the sessile fauna and sponge infauna was attributed a feeding guild (suspension/filter feeder, predator, deposit feeder/grazer); this characterization was based mainly on information available in Henry et al. (2013a). For a number of species, information on the feeding type was collected from Vader (1983) (amphipods), Neves and Omena (2003) (polychaetes), Nielsen and Riisgard (1998), Bader and Schafer (2005) (bryozoans). For two species the characterization of their feeding type was not possible due to the absence of sufficient taxonomic resolution.

\section{Data analysis}

The software PRIMER6 (Primer-E Ltd; Clarke and Warwick 2001) was used for the analyses of community structure. Data on the number of individuals and dry biomass, both normalized to volume of microhabitat, were fourth-root transformed and were used in the calculation of 
Fig. 2 a Spongosorites coralliophaga at Mingulay Reef Complex (MRC), b $S$. coralliophaga at Logachev Mound (LM), c Outer surface of $S$. coralliophaga colonized by a diverse faunal community, d internal canals and cavities, e underlying coral rubble colonized by $S$. coralliophaga

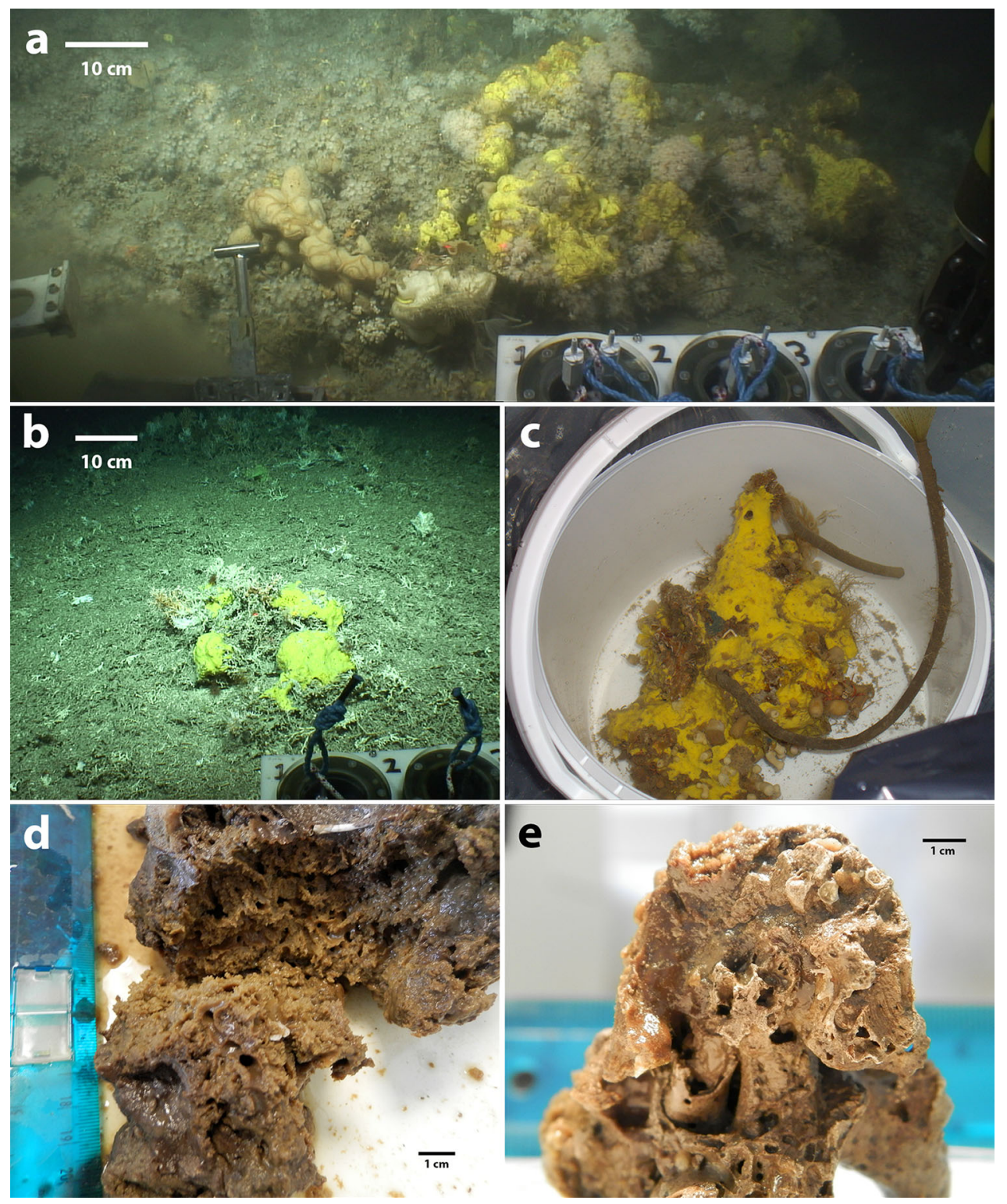

Bray-Curtis similarities and similarity matrices. Based on these matrices, non-metric multi-dimensional scaling (nMDS) 2-dimensional (2D) plots were constructed incorporating the four groups of samples mentioned above. In the constructed 2D plots, the values of stress were lower than 0.2 indicating a good ordination (Clarke 1993; Clarke and Warwick 2001). One-way analysis of similarities (ANOSIM) was carried out to check for significant differences between groups (i.e., MRC sponge vs. MRC coral rubble, MRC sponge vs. LM sponge, MRC coral rubble vs. LM coral rubble, and LM sponge vs. LM coral rubble), using data of individuals $\mathrm{cm}^{-3}$ microhabitat and dry biomass $\mathrm{cm}^{-3}$ microhabitat. These data were also used to identify the species that were responsible for the average dissimilarity between groups (SIMPER analysis). From the analyses mentioned above, we had to exclude two outlier samples-one sponge sample from LM and one coral rubble sample from $\mathrm{MRC}$ - which skewed the presentation of the nMDS 2D plots.

PRIMER6 was also used to calculate two biodiversity indices, Shannon-Wiener $H^{\prime}$ (estimated using Log e) and Pielou's evenness $J^{\prime}$ (Pielou 1975). For these two biodiversity indices, and for the number of species $S \mathrm{~cm}^{-3}$ microhabitat, the number of individuals $\mathrm{cm}^{-3}$ microhabitat, and the dry biomass $\mathrm{cm}^{-3}$ microhabitat, the normality of the distributions was checked with the Shapiro-Wilk test. In the case of normal distributions and equal variances, the existence of significant differences between groups was 
Table 2 Taxonomic groups living in association with Spongosorites coralliophaga and its underlying coral rubble in the cold-water coral reefs (CWRs) of the Mingulay Reef Complex (MRC) and Logachev Mound (LM) in the northeast Atlantic Ocean

\begin{tabular}{|c|c|c|c|c|c|c|}
\hline \multirow[t]{2}{*}{ Taxonomic group } & \multicolumn{6}{|c|}{ Locations and microhabitats } \\
\hline & $\begin{array}{l}\text { MRC } \\
\text { sponge } \\
\text { outer surface }\end{array}$ & $\begin{array}{l}\text { MRC } \\
\text { sponge } \\
\text { inner surface }\end{array}$ & $\begin{array}{l}\text { MRC } \\
\text { coral } \\
\text { rubble }\end{array}$ & $\begin{array}{l}\text { LM } \\
\text { sponge } \\
\text { outer surface }\end{array}$ & $\begin{array}{l}\text { LM } \\
\text { sponge } \\
\text { inner surface }\end{array}$ & $\begin{array}{l}\text { LM } \\
\text { coral } \\
\text { rubble }\end{array}$ \\
\hline \multicolumn{7}{|l|}{ Foraminifera } \\
\hline Morphotype 1 foraminifera & $+^{\mathrm{a}}$ & $+{ }^{\mathrm{b}}$ & $+^{c}$ & & & $+/+^{\mathrm{d}}$ \\
\hline Morphotype 2 foraminifera & & + & & & & \\
\hline Morphotype 3 foraminifera & & $+^{e} *$ & & & & \\
\hline \multicolumn{7}{|l|}{ Porifera } \\
\hline Haliclona (Haliclona) urceolus (Rathke and Vahl, 1806) & + & & & & & \\
\hline Poecillastra compressa (Bowerbank, 1866) & + & & & & & \\
\hline Porifera sp. & + & & & & & \\
\hline \multicolumn{7}{|l|}{ Hydrozoa } \\
\hline Acryptolaria conferta (Allman, 1877) & & & & & & + \\
\hline Clytia hemisphaerica (Linnaeus, 1767) & $+^{\mathrm{f}}$ & & & & & \\
\hline Halecium labrosum Alder, 1859 & & & + & & & \\
\hline Halecium muricatum (Ellis and Solander, 1786) & & & + & & & \\
\hline Halecium sp. & + & $+*$ & & & & \\
\hline Hydrozoa sp. & & & & + & & \\
\hline Kirchenpaueria sp. & + & & & & & \\
\hline Modeeria rotunda (Quoy and Gaimard, 1827) & $+^{\mathrm{a}, \mathrm{b}}$ & & & & & \\
\hline Rosalinda williami Totton, 1949 & $+/+^{\mathrm{g}}$ & & & & & \\
\hline Zanclea sessilis (Gosse, 1853) & + & & & & & \\
\hline Zygophylax pinnata (Sars, 1873) & & & & & & + \\
\hline \multicolumn{7}{|l|}{ Anthozoa } \\
\hline Anthozoa sp. & + & & & & & \\
\hline Corynactis viridis Allman, 1846 & & & & + & & \\
\hline Edwardsiella carnea (Gosse, 1856) & & + & & & & \\
\hline cf Edwardsiella loveni & & & & & & + \\
\hline Paraedwardsia sarsii (Dueben and Koren, 1847) & & & & + & & \\
\hline Parazoanthus anguicomus (Norman, 1868) & $+/+^{\mathrm{h}}$ & $+*$ & + & + & & + \\
\hline Telestula sp. & & & & & & + \\
\hline \multicolumn{7}{|l|}{ Nematoda } \\
\hline Nematoda sp. & & & $?$ & & & \\
\hline \multicolumn{7}{|l|}{ Polychaeta } \\
\hline cf Aphroditidae & & & & & & $?$ \\
\hline Bispira volutacornis (Montagu, 1804) & + & & & & & \\
\hline Branchiomma bombyx (Dalyell, 1853) & & & $?$ & & & \\
\hline Capitella sp. & & & & & & $?$ \\
\hline Eunice dubitata Fauchald, 1974 & & & $?$ & & & $?$ \\
\hline Eunice pennata (Müller, 1776) & & & $?$ & & & \\
\hline Euphrosine cf borealis & & & $?$ & & & $?$ \\
\hline cf Fimbriosthenelais zetlandica & & & $?$ & & & \\
\hline Haplosyllis spongicola (Grube, 1855) & & + & & & & $?$ \\
\hline cf Leocrates atlanticus & & & & & & $?$ \\
\hline Lepidonotus sp. & & & $?$ & & & \\
\hline Lumbrineris tetraura (Schmarda, 1861) & & & & & & $?$ \\
\hline Myrianida sp. 1 & & & $?$ & & & \\
\hline
\end{tabular}


Table 2 continued

Taxonomic group

Locations and microhabitats

\begin{tabular}{|c|c|c|c|c|c|}
\hline $\begin{array}{l}\text { MRC } \\
\text { sponge } \\
\text { outer surface }\end{array}$ & $\begin{array}{l}\text { MRC } \\
\text { sponge } \\
\text { inner surface }\end{array}$ & $\begin{array}{l}\text { MRC } \\
\text { coral } \\
\text { rubble }\end{array}$ & $\begin{array}{l}\text { LM } \\
\text { sponge } \\
\text { outer surface }\end{array}$ & $\begin{array}{l}\text { LM } \\
\text { sponge } \\
\text { inner surface }\end{array}$ & $\begin{array}{l}\text { LM } \\
\text { coral } \\
\text { rubble }\end{array}$ \\
\hline
\end{tabular}

Myrianida sp. 2

Nereimyra punctata (Müller, 1788)

?

cf Notophyllum foliosum

cf Sabellidae

Scalibregmatidae sp.

Serpula vermicularis Linnaeus, 1767

Sigalionidae sp.

Syllidae sp.

Terebellidae sp.

Trypanosyllis zebra (Grube, 1860)

Entoprocta

Pedicellina hispida Ryland, 1965

Crustacea

Amphipoda sp. 1

Amphipoda sp. 2

Amphipoda sp. 3

Amphipoda sp. 4

Aristias neglectus Hansen, 1888

Galathea strigosa (Linnaeus, 1761)

Janira maculosa Leach, 1814

$+$

cf Laetmatophilus tuberculatus

Munna sp.

Scalpellum scalpellum (Linnaeus, 1767)

Mollusca

Asperarca nodulosa (O. F. Müller, 1776)

Berthella sp.

Delectopecten vitreus (Gmelin, 1791)

cf Diodora graeca

Emarginula fissura (Linnaeus, 1758)

Hiatella arctica (Linnaeus, 1767)

Modiolula phaseolina (Philippi, 1844)

Heteranomia squamula (Linnaeus, 1758)

Lima marioni Fischer, 1882

Nudibranchia sp.

Palliolum striatum (O. F. Müller, 1776)

Pseudamussium sulcatum (Müller O. F., 1776)

Puncturella noachina (Linnaeus, 1771)

Solenogastres sp.

cf Tonicella marmorea

Bryozoa

Chartella barleei (Busk, 1860)

Candidae sp.

Disporella hispida (Fleming, 1828)

Idmidronea atlantica (Forbes, in Johnston, 1847)

Reteporella beaniana (King, 1846)

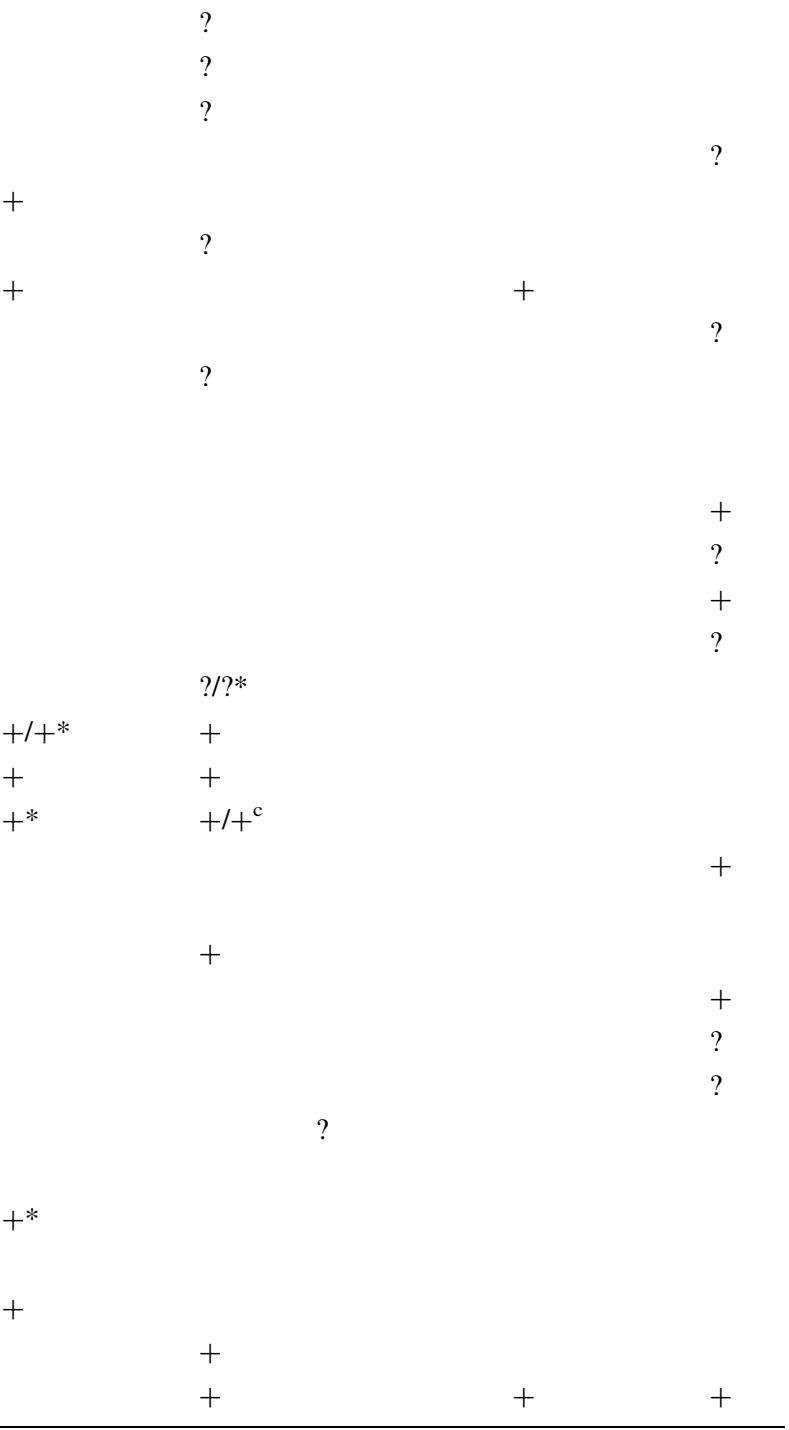


Table 2 continued

\begin{tabular}{|c|c|c|c|c|c|c|}
\hline \multirow[t]{2}{*}{ Taxonomic group } & \multicolumn{6}{|c|}{ Locations and microhabitats } \\
\hline & $\begin{array}{l}\text { MRC } \\
\text { sponge } \\
\text { outer surface }\end{array}$ & $\begin{array}{l}\text { MRC } \\
\text { sponge } \\
\text { inner surface }\end{array}$ & $\begin{array}{l}\text { MRC } \\
\text { coral } \\
\text { rubble }\end{array}$ & $\begin{array}{l}\text { LM } \\
\text { sponge } \\
\text { outer surface }\end{array}$ & $\begin{array}{l}\text { LM } \\
\text { sponge } \\
\text { inner surface }\end{array}$ & $\begin{array}{l}\text { LM } \\
\text { coral } \\
\text { rubble }\end{array}$ \\
\hline Schizomavella linearis (Hassall, 1841) & & + & & & & \\
\hline \multicolumn{7}{|l|}{ Brachiopoda } \\
\hline Terebratulina retusa (Linnaeus, 1758) & & & + & & & \\
\hline T. septentrionalis (Couthouy, 1838) & & & & & & + \\
\hline Brachiopoda sp. & & $+^{*}$ & & & & \\
\hline \multicolumn{7}{|l|}{ Echinodermata } \\
\hline Cidaris cidaris (Linnaeus, 1758) & & & & & & $?$ \\
\hline cf Goniasteridae sp. & & & & & & $?$ \\
\hline Holothuroidea sp. & & & & & & $?$ \\
\hline Ophiothrix fragilis (Abildgaard, in O.F. Müller, 1789) & $?$ & & & & & \\
\hline Ophiura ophiura (Linnaeus, 1758) & $?$ & & & $?$ & & \\
\hline Ophiuroidea sp. & $?$ & & & & & \\
\hline Ophioctenella acies Tyler et al. 1995 & & & & ? & & \\
\hline Porania (Porania) pulvillus (O.F. Müller, 1776) & & & $?$ & & & \\
\hline \multicolumn{7}{|l|}{ Ascidiacea } \\
\hline Ascidia mentula Müller, 1776 & & & & & & + \\
\hline Polycarpa pomaria (Savigny, 1816) & + & $+^{*}$ & & & & \\
\hline \multicolumn{7}{|c|}{$\begin{array}{l}\text { Allocation of microhabitat has only been carried out for sessile fauna and sponge infauna. Footnotes denote secondary biogenic structures; ?, } \\
\text { microhabitat not known with precision; *, specimen's remnants/no tissue presence/shell overgrown by S. coralliophaga }\end{array}$} \\
\hline \multicolumn{7}{|l|}{ a Halecium sp. } \\
\hline \multicolumn{7}{|l|}{ b Unidentified hydrozoan stems } \\
\hline \multicolumn{7}{|l|}{ c Halecium muricatum } \\
\hline \multicolumn{7}{|l|}{ d Zygophylax pinnata } \\
\hline \multicolumn{7}{|c|}{ e Recorded in microscopic sections of Poecillastra compressa inner surface } \\
\hline \multicolumn{7}{|l|}{ Modeeria rotunda } \\
\hline \multicolumn{7}{|l|}{ g Tubeworm casings } \\
\hline \multicolumn{7}{|l|}{ h Poecillastra compressa } \\
\hline \multicolumn{7}{|l|}{ i Bispira volutacornis } \\
\hline j Rosalinda williami & & & & & & \\
\hline k Polycarpa pomaria & & & & & & \\
\hline
\end{tabular}

tested with a two-sample $t$ test. In the case of normal distributions with unequal variances, a Welch's two-sample $t$ test was used. When the distribution was not normal, a Wilcoxon rank sum test was carried out or a square-root transformation was performed where appropriate. Correlations between microhabitat volume and $S, H^{\prime}, J^{\prime}$, total number of individuals and total dry biomass were calculated using Pearson's product-moment correlation coefficient or Spearman's rank correlation coefficient. Squareroot transformation was used where appropriate. Examination of (a) differences between groups and (b) correlations were carried out in the statistical analysis environment R (R Core Team 2013).

\section{Results}

\section{Community composition and structure}

In total, 91 species of sessile and mobile fauna belonging to 12 phyla were recorded (Table 2) and comprised 2525 individuals. The highest species numbers were attributed to Annelida (25.3\%), Cnidaria (19.8\%), and Mollusca $(16.5 \%)$. The relative presence of the taxonomic groups of the sessile fauna and sponge infauna in each of the microhabitats can be seen in Fig. 3. A total of $34.1 \%$ of the species were recorded solely at LM, $53.8 \%$ solely at MRC, and only $12.1 \%$ were common between the two 
Fig. 3 Relative contribution (\%) of taxonomic groups of the sessile fauna and sponge infauna to each of the microhabitats in Mingulay Reef Complex (MRC) and Logachev Mound (LM). Calculations based on back-transformed data of arcsine numbers. Bars denote the mean values. Error bars show upper and lower $95 \% \mathrm{CI}$

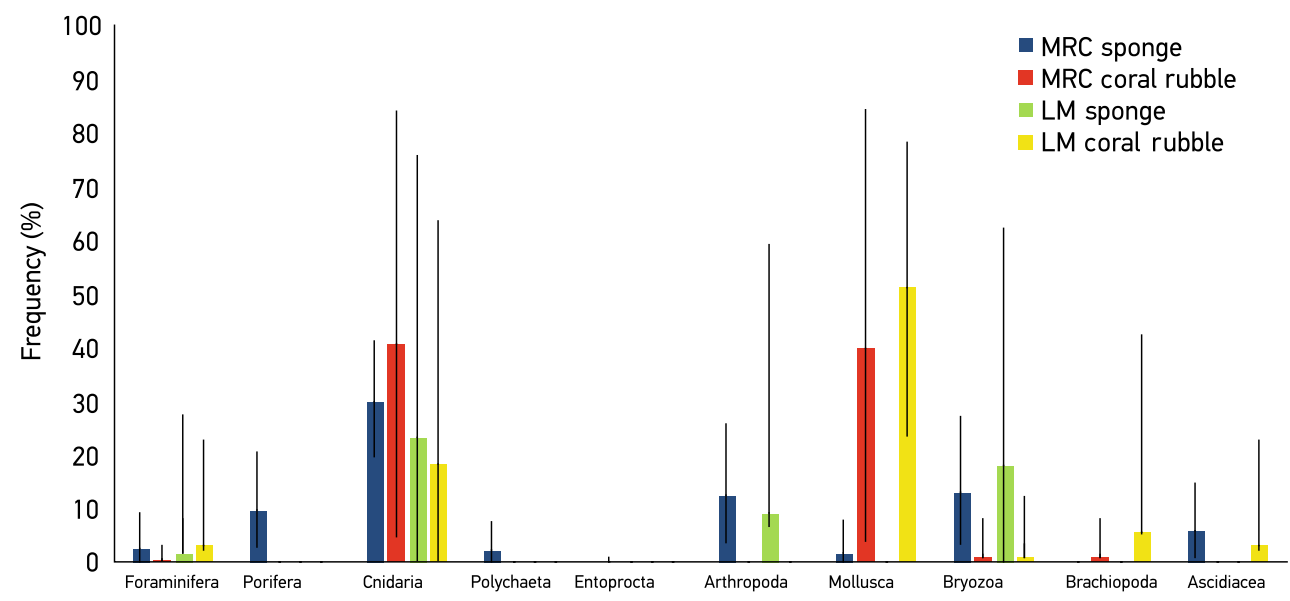

regions. The common species included the anthozoan Parazoanthus anguicomus (Norman, 1868), the polychaetes Eunice dubitata (Fauchald, 1974), Haplosyllis spongicola (Grube, 1855), Trypanosyllis zebra (Grube, 1860), Euphrosine cf borealis, Sigalionidae sp., Syllidae sp., the isopod Janira maculosa (Leach, 1814), the bryozoan Reteporella beaniana (King, 1846), the ophiuroid Ophiura ophiura (Linnaeus, 1758) and "Morphotype 1 foraminifera". Out of the 60 species recorded at MRC, eight were recorded for first time on this CWR including the hydrozoans Halecium labrosum (Alder, 1859) and Kirchenpaueria sp., the polychaetes Myrianida sp.1, Bispira volutacornis (Montagu, 1804), Eunice dubitata, Eunice pennata (Müller, 1776), and Haplosyllis spongicola, and the cirripedian Scalpellum scalpellum (Linnaeus, 1767). Also, to the best of our knowledge, this is the first record of the ophiuroid Ophioctenella acies Tyler et al. 1995 in a non-chemosynthetic ecosystem (Stöhr and Segonzac 2005).

In both regions only a small number of species (12 in MRC and 2 in LM) were found inside the sponge (Table 2). Infauna constituted a minor component, both in terms of abundance (total number of individuals) and dry biomass (total $\mathrm{mg}$ ), of the total sponge-associated fauna in MRC, but had a higher contribution in LM (Fig. 4). In regard to the infauna, species with the highest number of individuals in total included the amphipod Aristias neglectus (62 specimens), and the species with the highest biomass was the bryozoan Reteporella beaniana (156.8 mg).

At MRC, a number of epifaunal species were found on secondary biological structures, for example "Morphotype 1 foraminifera" were exclusively recorded on the stems of the hydroids Halecium sp. and H. muricatum (Ellis and Solander, 1786), and S. scalpellum was found exclusively attached to the tube of B. volutacornis. At LM, the only secondary biological structure was the hydroid Zygophylax pinnata (Sars, 1873), which hosted a small number of "Morphotype 1 foraminifera". Furthermore, at MRC, a number of species were present at more than one microhabitat, e.g., Hiatella arctica was recorded both inside sponge as well as on coral rubble, while Heteranomia squamula was recorded on coral rubble as well as on the stems of the hydroid Rosalinda williami Totton, 1949 (Table 2). At LM associations, only "Morphotype 1 foraminifera" were recorded both on hydroid stems and coral rubble.

The nMDS 2D-ordination plots based on number of individuals $\mathrm{cm}^{-3}$ microhabitat and dry biomass $\mathrm{cm}^{-3}$ microhabitat for sessile fauna and sponge infauna revealed a trend for distinct groups both in terms of location/depth and microhabitat (Fig. 5). These trends were also confirmed by one-way ANOSIM analysis using individuals $\mathrm{cm}^{-3}$ microhabitat and dry biomass $\mathrm{cm}^{-3}$ microhabitat (Table 3). All the groups that were compared showed significant differences; the highest values recorded were between MRC sponge and LM sponge and the lowest values were between MRC coral rubble and LM coral rubble. The discrimination between LM sponge and LM coral rubble samples was higher than between MRC sponge and MRC coral rubble samples. The high $R$ values confirmed the limited overlap between different microhabitats within the same location, as well as in the same type of microhabitat between the two different locations.

In terms of the number of individuals $\mathrm{cm}^{-3}$ microhabitat, SIMPER analysis revealed an average dissimilarity of 86.3 between MRC sponge and MRC coral rubble. The main species driving this dissimilarity were $P$. anguicomus (15.1\% contribution in the average dissimilarity), Candidae sp. (10.9\%), and A. neglectus (10\%), all of which were more abundant in MRC sponge. Parazoanthus anguicomus (14.6\%), R. beaniana (10.8\%) and Candidae sp. $(8.7 \%)$ were the species leading the average dissimilarity of 89.4 recorded between MRC sponge and LM 
a MRC - Abundance

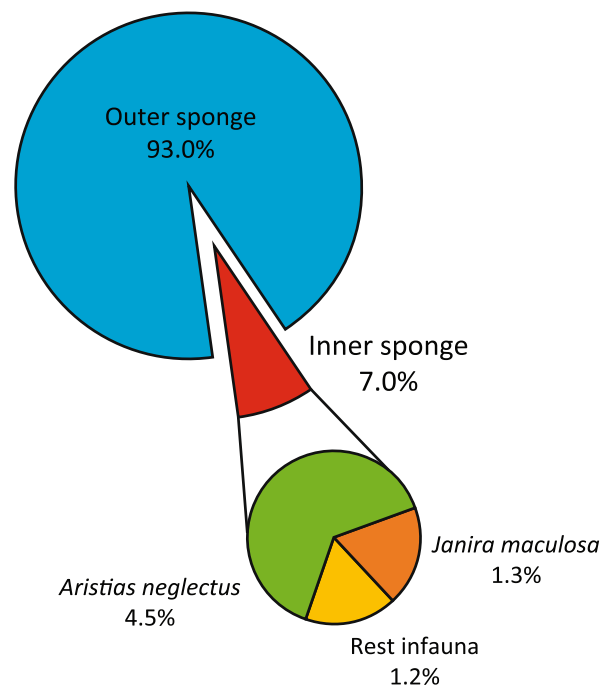

C LM - Abundance

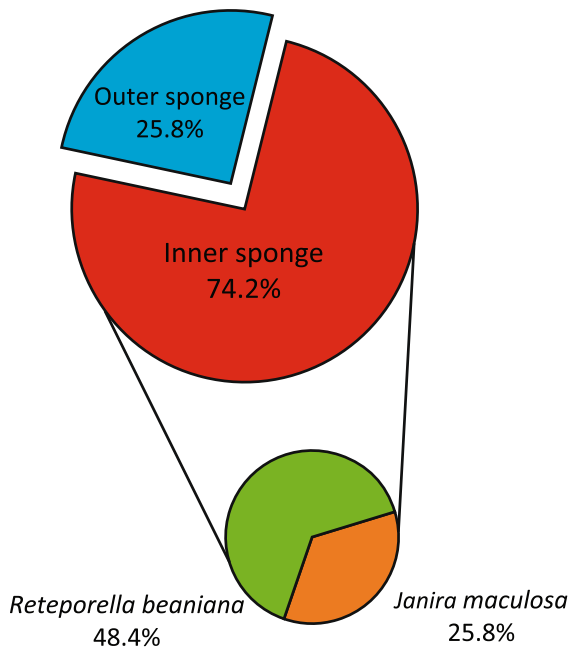

b MRC - Dry biomass

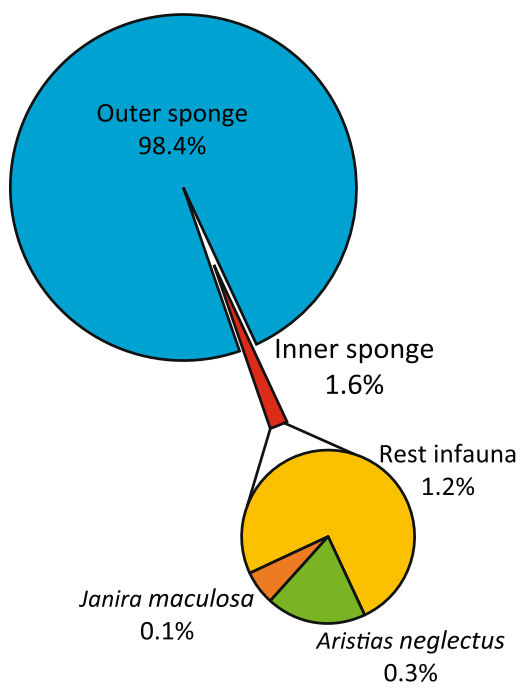

d LM - Dry biomass

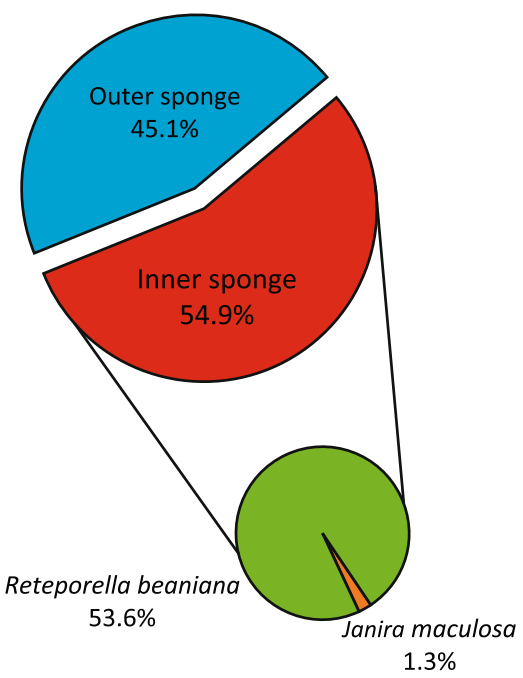

Fig. 4 Charts showing the shares of sponge sessile epifauna ("outer sponge") and sponge infauna ("inner sponge") in terms of abundance (total number of individuals) and dry biomass (total mg) in Mingulay Reef Complex (MRC) and Logachev Mound (LM)

sponge. The average dissimilarity between MRC coral rubble and LM coral rubble was 88.5 ; the species A. nodulosa, Parazoanthus anguicomus, and Pseudamussium sulcatum had a cumulative contribution of $48.4 \%$. The average dissimilarity between LM sponge and LM coral rubble was 89.3. This dissimilarity was mainly attributed to the species A. nodulosa (17.1\%), R. beaniana $(15.3 \%)$, and $J$. maculosa (11.6\%). SIMPER analysis based on dry biomass $\mathrm{cm}^{-3}$ microhabitat revealed overall similar patterns to those described above for abundance. Exceptions include a leading contribution of Poecillastra compressa to the average dissimilarity between MRC sponge and MRC coral rubble, and MRC sponge and LM sponge. In addition there was a leading contribution of
Pseudamussium sulcatum to the average dissimilarity between LM sponge and LM coral rubble.

\section{Diversity indices, number of species $\mathrm{cm}^{-3}$, number \\ of individuals $\mathrm{cm}^{-3}$, and dry biomass $\mathrm{cm}^{-3}$ microhabitat for sessile fauna and sponge infauna}

There were no significant differences for the parameters $H^{\prime}$ and $J^{\prime}$ in most of the examined pairs of groups. Statistically significant differences were found for the number of species $\mathrm{cm}^{-3}$, number of individuals $\mathrm{cm}^{-3}$, and dry biomass $\mathrm{cm}^{-3}$ microhabitat (Table 4; Fig. 6a-f). The number of individuals $\mathrm{cm}^{-3}$ and dry biomass $\mathrm{cm}^{-3}$ microhabitat were lower in LM sponge than MRC sponge samples, while the 


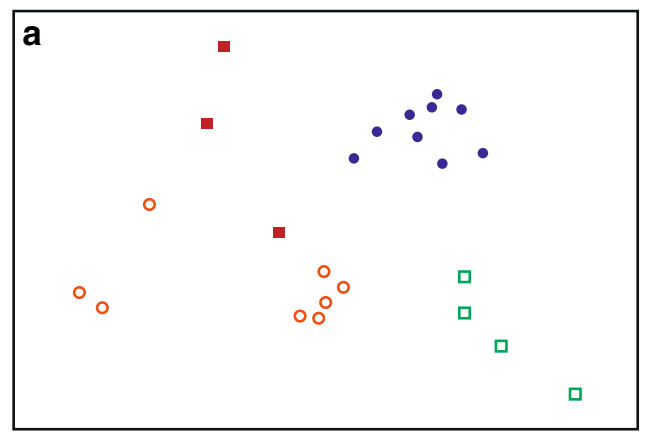

MRC sponge $O$ MRC coral rubble

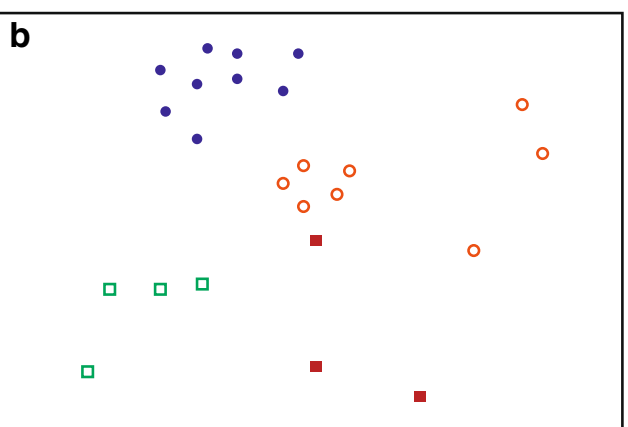

LM sponge $\square$ LM coral rubble
Fig. 5 2D nMDS plots of sponge and coral rubble microhabitats in Mingulay Reef Complex (MRC) and Logachev Mound (LM) based on number of individuals $\mathrm{cm}^{-3}$ microhabitat (a) and dry biomass $\mathrm{cm}^{-3}$ microhabitat (b). Data were fourth-root transformed and were used in the calculation of Bray-Curtis similarities. Stress values were 0.14 and 0.11 in (a) and (b), respectively

Table 3 Results of analysis of similarities (ANOSIM) for number of individuals $\mathrm{cm}^{-3}$ and dry biomass $\mathrm{cm}^{-3}$ in the Mingulay Reef Complex (MRC) and Logachev Mound (LM) sponge and coral rubble microhabitats

\begin{tabular}{llllll}
\hline Pairs of groups & \multicolumn{2}{l}{ Individuals $\mathrm{cm}^{-3}$} & & \multicolumn{2}{c}{ Dry biomass $\mathrm{cm}^{-3}$} \\
& & $R$ & $p$ level & & $R$ level \\
\hline MRC sponge & MRC coral rubble & 0.681 & 0.001 & 0.624 & 0.001 \\
MRC sponge & LM sponge & 0.981 & 0.005 & 0.985 & 0.005 \\
MRC coral rubble & LM coral rubble & 0.467 & 0.014 & 0.517 & 0.01 \\
LM sponge & LM coral rubble & 0.944 & 0.029 & 0.021 & 0.029 \\
\hline
\end{tabular}

$R$-statistic $(R)$ and $p$ level are given

opposite pattern was recorded between MRC coral rubble and LM coral rubble samples (Fig. 6a-f).

\section{Correlation of microhabitat volume with $S, H^{\prime}, J^{\prime}$, total number of individuals, and total dry biomass for sessile fauna and sponge infauna}

For MRC sponge samples, correlation analyses revealed a significant relationship between sponge volume and total species number $S(r=0.74, p=0.023)$, sponge volume and total number of individuals $(r=0.84, p=0.004)$, and sponge volume and total dry biomass $(r=0.78$, $p=0.011)$. Significant correlations were also found for MRC coral rubble samples between coral volume and total number of individuals $(r=0.72, p=0.029)$. In all other cases, there were no statistically significant correlations between the volume of the microhabitat and the examined parameters.

\section{Distribution of feeding types for sessile fauna and sponge infauna}

The fauna in the $S$. coralliophaga-coral rubble association included various feeding types (Fig. 7). At both locations, the sessile fauna that was living in the sponge or coral rubble microhabitats was composed mainly of suspension/filter feeders (Fig. 7).

\section{Discussion}

\section{Methodological considerations}

Due to logistical constraints (i.e., ROV time, availability of space in the biobox), it was not possible to collect coral rubble not colonized by $S$. coralliophaga during our survey. As sponges affect the small-scale hydrography and food supply in their vicinity (e.g., Maldonado et al. 2012), abundance and biomass of epifauna near the sponge might be slightly higher compared to coral rubble not colonized by $S$. coralliophaga, and our data hence overestimate average abundance and biomass. Sponge size and morphology between MRC and LM, on the other hand, were similar and therefore unlikely to have affected the comparison between sites. Similarly, the levels of species richness, abundance, and biomass described in the present study should be regarded as underestimates since (1) only a small number of associations could be examined in each location (due to logistical constraints), (2) a number of small motile species living in association with the 
Table 4 Results of analysis of variance for comparisons of Mingulay Reef Complex (MRC) and Logachev Mound (LM) sponge and coral rubble microhabitats for number of species $S \mathrm{~cm}^{-3}$, Shannon-Wiener
Index $H^{\prime}$, Pielou's evenness Index $J^{\prime}$, number of individuals $\mathrm{cm}^{-3}$ and dry biomass $\mathrm{cm}^{-3}$

\begin{tabular}{lllll}
\hline & $\begin{array}{l}\text { MRC sponge- } \\
\text { MRC coral rubble }\end{array}$ & $\begin{array}{l}\text { MRC sponge- } \\
\text { LM sponge }\end{array}$ & $\begin{array}{l}\text { MRC coral rubble- } \\
\text { LM coral rubble }\end{array}$ & $\begin{array}{l}\text { LM sponge-LM } \\
\text { coral rubble }\end{array}$ \\
\hline$S \mathrm{~cm}^{-3}$ & $0^{\#, * * *}$ & $-1.2522^{\dagger}$ & $2.2688^{\mathrm{a}, ¥}$ & $-1.0081^{\dagger}$ \\
$H^{\prime}$ & $0^{\#, * * *}$ & $7^{\#}$ & $27^{\#}$ & $0.3672^{\dagger}$ \\
$J^{\prime}$ & $0.4113^{\ddagger}$ & $4.6382^{\dagger, * * *}$ & $-1.1469^{\dagger}$ & $-4.4656^{\ddagger, *}$ \\
Individuals cm & $0^{\#, * * *}$ & $1^{\#, * *}$ & $2.0556^{\mathrm{a}, ¥}$ & $9^{\#}$ \\
Dry biomass cm & $-3.5807^{\ddagger, * *}$ & $-3.3382^{\ddagger, * *}$ & $2.9308^{\ddagger}$ & $2.0696^{\dagger}$
\end{tabular}

Values of two-sample $t$ test $^{\dagger}$, Welch's two-sample $t$ test $^{\ddagger}$, Wilcoxon rank sum test ${ }^{\#}$ and $p$ values $(* * * p \leq 0.001, * * 0.001<p \leq 0.01$, * $0.01<p \leq 0.05$, where no asterisks are shown, differences were not statistically significant) are given

${ }^{\text {a }}$ Data were square-root transformed
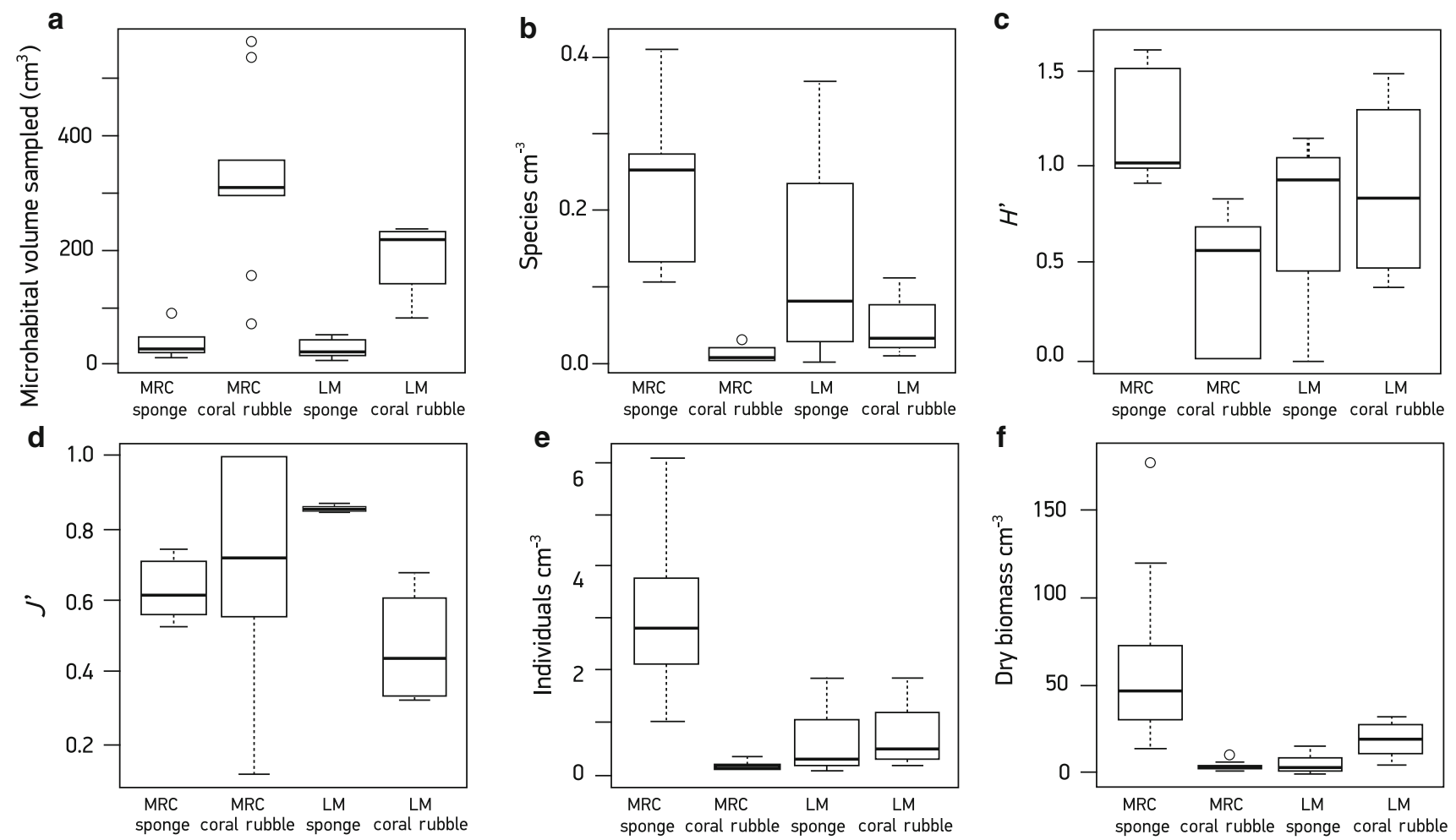

Fig. 6 Box plots of a microhabitat volume sampled $\left(\mathrm{cm}^{3}\right)$, b species number $\mathrm{cm}^{-3}$ microhabitat, c Shannon-Wiener Index, $H^{\prime}$, d Pielou's evenness Index, $J^{\prime}$, e number of individuals $\mathrm{cm}^{-3}$ microhabitat, $\mathbf{f}$ dry biomass $\mathrm{cm}^{-3}$ microhabitat in Mingulay Reef Complex (MRC) and Logachev Mound (LM). Lower and upper whiskers denote the data range (minimum-maximum values not considered to be outliers) demosponge-coral rubble association could have escaped during the sampling procedure, and (3) a number of fragile specimens were too heavily damaged during sampling to be identified and thus were excluded from any abundance/ biomass/diversity calculations. We therefore conclude that diversity at our study sites is comparable to a number of studies from shallow-water sites (e.g., Voultsiadou-Koukoura et al. 1987; Çinar et al. 2002; Neves and Omena 2003 and references therein; Ribeiro et al. 2003; Padua et al. 2013) where conditions enabled more comprehensive sampling. Finally, it should be mentioned that the risk of the cross-over by coral rubble fauna to the sponge during collection of samples from the seafloor was excluded since the comparisons between sponge and coral rubble microhabitats took into account solely the sessile fauna and sponge infauna. 
Fig. 7 Relative contribution (\%) of feeding types of sessile fauna and sponge infauna to each of the microhabitats in Mingulay Reef Complex (MRC) and Logachev Mound (LM). Calculations based on back-transformed data of arcsine numbers. Bars denote the mean values. Error bars show upper and lower $95 \% \mathrm{CI}$

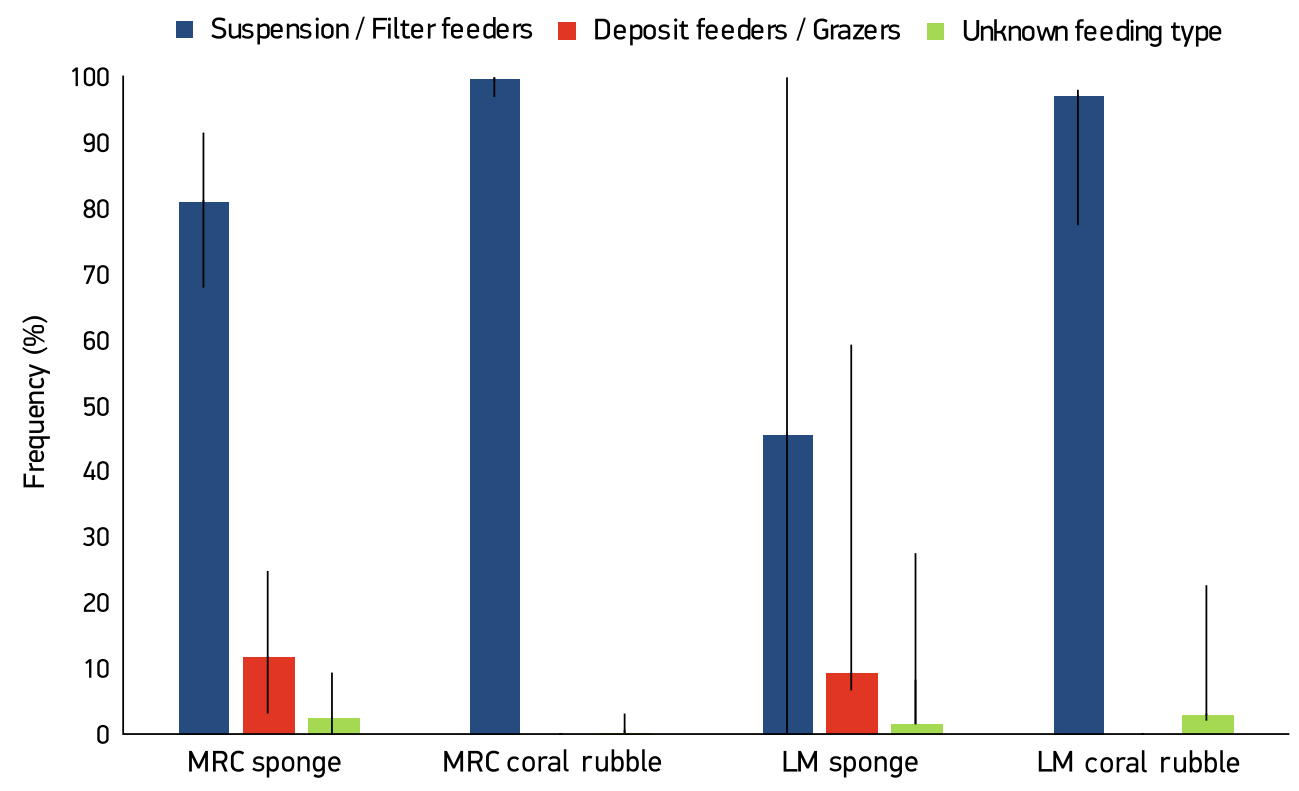

\section{Differences in community structure and possible drivers}

The nMDS and ANOSIM analyses on MRC and LM community structure showed distinct differences between the two regions. The small number of common species between the two regions, and the fact that species with high abundance/biomass in one region (i.e., the anthozoan Parazoanthus anguicomus in MRC, the bryozoan Reteporella beaniana in LM) occurred in low abundance/biomass in the other, indicate that patterns of species' bathymetric distributions were an important driver of differences in community structure between MRC and LM (Henry and Roberts 2007; Roberts et al. 2009; Henry et al. 2013b; van Soest and de Voogd 2013). Apart from species' bathymetric distributions, environmental parameters (e.g., speed of bottom currents, quantity and quality of food) may also play a role. Higher values of primary productivity at MRC than LM (Fehling et al. 2012) and higher concentrations of polyunsaturated fatty acids (PUFAs) on the MRC (Duineveld et al. 2012) versus the LM seafloor (Kiriakoulakis et al. 2007) are likely to have favored the development of a species-rich epifaunal community of suspension feeders recorded on the outer surfaces of MRC sponges. The development of this species-rich epifaunal community has likely further benefited from higher current speeds in MRC (up to $60 \mathrm{~cm} \mathrm{~s}^{-1}$; Davies et al. 2009) than LM (up to $30 \mathrm{~cm} \mathrm{~s}^{-1}$; Duineveld et al. 2007; Mohn et al. 2014).

Interestingly, diversity/abundance/biomass was higher in LM coral rubble than in MRC coral rubble, in contrast to findings between MRC sponge and LM sponge communities. The high values of abundance/biomass in LM coral rubble are attributed to Pseudamussium sulcatum and especially to Asperarca nodulosa whose bathymetric distribution extends from the sublittoral zone to the abyss (Oliver and Allen 1980). Bivalves are often reported as inhabitants of sponge canals (e.g., Çinar et al. 2002; Ribeiro et al. 2003; Schejter et al. 2012; Padua et al. 2013), but the relatively large size of $A$. nodulosa prevents it from settling in the canals of $S$. coralliophaga and thus specimens live attached to underlying coral rubble (see also Voultsiadou-Koukoura et al. 1987; Gherardi et al. 2001; Neves and Omena 2003). In contrast to the LM coral rubble, abundance and biomass of suspension/filter feeders in the MRC coral rubble was low; enhanced water flow conditions, and thus oxygenation/food supply, support the presence of suspension feeders in the LM coral rubble (Lenihan 1999; McQuaid and Mostert 2010; Whitman and Reidenbach 2012). This is particularly interesting, given that bottom currents are stronger at MRC than LM (see above) and supports the suggestion that small-scale gradients of environmental conditions can favor the proliferation of specific feeding types/taxonomic groups, which in turn can have an impact on community species composition, abundance and biomass (Çinar et al. 2002 and references therein).

The importance of small-scale gradients in the configuration of community structure is further highlighted by the comparison between MRC sponge and MRC coral rubble; high water movement on sponge surface facilitates the presence of a species-rich community of suspension feeders (Peattie and Hoare 1981; see also Raes and Vanreusel 2006). In both MRC sponge and coral rubble, the anthozoan Parazoanthus anguicomus was among the species with high values of abundance and biomass, which had an 
important contribution to the higher similarity that was found when comparing MRC sponges to MRC coral rubble than LM sponges to LM coral rubble. This species' high abundance and biomass are likely due to its high fecundity (Ryland 2000) and flexibility in feeding (Buhl-Mortensen 2001; Mueller et al. 2014).

\section{The role of $S$. coralliophaga as a biological structure}

Previous studies on sponge associates have revealed species-rich communities inhabiting sponge canals (e.g., Westinga and Hoetjes 1981; Duarte and Nalesso 1996) and sponges acting as a nursery ground (Schejter et al. 2012; Padua et al. 2013) providing shelter against strong currents (Peattie and Hoare 1981) and/or predators (Magnino et al. 1999a). In contrast to previous studies on sponge infauna, we recorded only a small number of species living inside $S$. coralliophaga at both MRC and LM. The reasons for this are unclear but the facts that only a few small specimens were found inside the sponges and that a number of bivalves and brachiopods were found to be overgrown by $S$. coralliophaga, suggest that the conditions inside $S$. coralliophaga probably do not favor infaunal organisms (Magnino et al. 1999b; Skilleter et al. 2005). The most abundant infaunal species was the amphipod Aristias neglectus which has low host specificity and has been found across various invertebrates (Vader 1983; Kilgallen 2010); its presence in the vascular cavities of sea anemones has been related to feeding on partially digested food particles (Vader 1983) and thus its presence inside S. coralliophaga may also be related to its feeding on food particles captured by the sponge.

The sessile fauna colonizing S. coralliophaga and coral rubble at MRC and LM was mainly composed of cnidarians, molluscs, and bryozoans. Previous studies on the faunal composition of coral rubble zones in the North Atlantic Ocean have revealed that their sessile fauna is rich in cnidarians (Roberts et al. 2008; Wienberg et al. 2008) and sponges (Freiwald and Wilson 1998; Freiwald et al. 2002; Purser et al. 2013). In addition, cnidarians and molluscs had the highest number among sessile species in Porcupine Seabight samples from on- and off-mound sites (Henry and Roberts 2007), while bryozoans were the most speciose group among sessile fauna inhabiting blocks of live and dead corals in the Faroe Shelf (Jensen and Frederiksen 1992). Finally, bryozoans and hydroids had the highest number of sessile species in reef framework habitats in the MRC (Henry et al. 2013a).

The colonization of the outer surface of $S$. coralliophaga by a diverse community of sessile suspension feeders in MRC suggests that this sponge acts as a major settlement substrate in that region (see also Klitgaard 1995; Montenegro-Gonzalez and Acosta 2010; De Campos et al.
2012; Padua et al. 2013). This is further emphasized by the much higher species richness, abundance, and dry biomass in MRC sponges compared to MRC coral rubble. In addition, each of these two microhabitats had a different combination of characteristics (e.g., hydrography, food supply) that increased habitat complexity and underpinned species coexistence and thus enhanced benthic biodiversity (McGuiness and Underwood 1986; Stuart et al. 2003; Hewitt et al. 2008; Schaal et al. 2011; Buhl-Mortensen et al. 2010; Padua et al. 2013). In contrast to MRC, S. coralliophaga did not act as a biological structure in LM; this fact is probably due to a combination of factors including species' bathymetric distributions, bottom currents, and food supply in LM (see above for details).

The taxonomic composition of the $S$. coralliophagacoral rubble associations in MRC closely resembles the fauna described in Henry et al. (2013a) for that region; this high similarity indicates that the organisms living in association with $S$. coralliophaga and underlying coral rubble constitute a subset of the benthic fauna of the wider MRC area. On this basis we suggest that the relationship between $S$. coralliophaga and its inhabitants is largely facultative (see also Klitgaard 1995). The close resemblance between $S$. coralliophaga-coral rubble association and wider MRC fauna suggests that (1) the collection of $S$. coralliophaga-coral rubble associations could be used as an alternative, less-destructive approach (e.g., compared to box-coring) for future studies on reef biodiversity (2) $S$. coralliophaga-coral rubble associations could be used for studies of structure and functionality of CWR food webs. Finally, our findings highlight the necessity for studies in the ecology of deep-sea sponge grounds (Hogg et al. 2010; Bo et al. 2012; Beazley et al. 2013).

Acknowledgments The authors would like to thank Bill Richardson (Master), the crew of the RRS James Cook, Will Handley and the Holland-I ROV team. We also thank all the specialists in taxonomy that provided important help with identification of species: Professor Paul Tyler (ophiuroids), Dr. Tammy Horton (amphipods), Dr. Graham Oliver (bivalves), Dr. Rob van Soest (sponges), Susan Chambers, Peter Garwood, Sue Hamilton, Raimundo Blanco Pérez (polychaetes). Also we would like to thank Val Johnston (University of Aberdeen) for her contribution to cruise preparations and John Polanski (University of Aberdeen) for his help onboard the RRS James Cook. Special thanks to Dr. Alexios P. Lolas (University of Thessaly, Greece) for all the artwork. Funding for the JC073 cruise was provided by the Natural Environment Research Council (NERC) UK Ocean Acidification (UKOA) research programme's Benthic Consortium project (NE/H017305/1 to JMR). JMR acknowledges support from Heriot-Watt University's Environment and Climate Change theme. GK was funded by a Marine Alliance for Science and Technology for Scotland (MASTS) Ph.D. scholarship.

Open Access This article is distributed under the terms of the Creative Commons Attribution 4.0 International License (http://crea tivecommons.org/licenses/by/4.0/), which permits unrestricted use, distribution, and reproduction in any medium, provided you give 
appropriate credit to the original author(s) and the source, provide a link to the Creative Commons license, and indicate if changes were made.

\section{References}

Bader B, Schafer P (2005) Impact of environmental seasonality on stable isotope composition of skeletons of the temperate bryozoan Cellaria sinuosa. Palaeogeogr Palaeoclimatol Palaeoecol 226:58-71

Beaulieu SE (2001) Life on glass houses: sponge stalk communities in the deep sea. Mar Biol 138:803-817

Beazley LI, Kenchington EL, Murillo FJ, del Mar Sacau M (2013) Deep-sea sponge grounds enhance diversity and abundance of epibenthic megafauna in the Northwest Atlantic. ICES J Mar Sci 70:1471-1490

Bell JJ (2008) The functional roles of marine sponges. Estuar Coast Shelf Sci 79:341-353

Bo M, Bertolino M, Bavestrello G, Canese S, Giusti M, Angiolillo M, Pansini M, Taviani M (2012) Role of deep sponge grounds in the Mediterranean Sea: a case study in southern Italy. Hydrobiol 687:163-177

Buhl-Mortensen P (2001) Aquarium observations on the deep-water coral Lophelia pertusa (L., 1758) (Scleractinia) and selected associated invertebrates. Ophelia 54:83-104

Buhl-Mortensen L, Vanreusel A, Gooday AJ, Levin LA, Priede IG, Buhl-Mortensen P, Gheerardyn H, King NJ, Raes M (2010) Biological structures as a source of habitat heterogeneity and biodiversity on the deep ocean margins. Mar Ecol 31:21-50

Çinar ME, Tuncer K, Ergen Z, Sezgin M (2002) Zoobenthosinhabiting Sarcotragus muscarum (Porifera: Demospongiae) from the Aegean Sea. Hydrobiol 482:107-117

Clarke KR (1993) Non-parametric multivariate analyses of changes in community structure. Aust J Ecol 18:117-143

Clarke KR, Warwick RM (2001) Change in marine communities: an approach to statistical analysis and interpretation, 2nd edn. PRIMER-E, Plymouth

Davies AJ, Duineveld GCA, Lavaleye MSS, Bergman MJN, van Haren H, Roberts JM (2009) Downwelling and deep-water bottom currents as food supply mechanisms to the cold-water coral Lophelia pertusa (Scleractinia) at the Mingulay Reef complex. Limnol Oceanogr 54:620-629

De Campos CJA, Migotto AE, Pinheiro U, Marques AC (2012) Sponges as substrata and early life history of the tubulariid Zyzzyzus warreni (Cnidaria:Hydrozoa) in the Sao Sebastiao Channel, Brazil. Mar Biol Res 8:573-583

de Goeij JM, van Oevelen D, Vermeij MJA, Osinga R, Middelburg JJ, de Goeij AFPM, Admiraal W (2013) Surviving in a Marine Desert: The Sponge Loop Retains Resources Within Coral Reefs. Science 342:108-110

Duarte L, Nalesso R (1996) The sponge Zygomycale parishii (Bowerbank) and its endobiotic fauna. Estuar Coast Shelf Sci 42:139-151

Duineveld GCA, Lavaleye MSS, Bergman MJN, de Stigter H, Mienis F (2007) Trophic structure of a cold-water coral mound community (Rockall Bank, NE Atlantic) in relation to the near-bottom particle supply and current regime. Bull Mar Sci 81:449-467

Duineveld GCA, Jeffreys RM, Lavaleye MSS, Davies AJ, Bergman MJN, Watmough T, Witbaard R (2012) Spatial and tidal variation in food supply to shallow cold-water coral reefs of the Mingulay Reef complex (Outer Hebrides, Scotland). Mar Ecol Prog Ser 444:97-115
Fehling J, Davidson K, Bolch CJS, Brand TD, Narayanaswamy BE (2012) The relationship between phytoplankton distribution and water column characteristics in north west European shelf sea waters. PLoS One 7. doi:10.1371/journal.pone. 0034098

Findlay H, Hennige SJ, Wicks LC, Moreno Navas J, Malcolm E, Woodward S, Roberts JM (2014) Fine-scale nutrient and carbonate system dynamics around cold-water coral reefs in the northeast Atlantic. Sci Rep 4. doi:10.1038/srep03671

Fiore CL, Jutte PC (2010) Characterization of macrofaunal assemblages associated with sponges and tunicates collected off the southeastern United States. Invertebr Biol 129:105-120

Fiore CL, Jarett JK, Olson ND, Lesser MP (2010) Nitrogen fixation and nitrogen transformations in marine symbioses. Trends Microbiol 18:455-463

Freiwald A, Wilson JB (1998) Taphonomy of modern deep, coldtemperate water coral reefs. Hist Biol: an Intern J Paleobiol 13:37-52

Freiwald A, Hühnerbach V, Lindberg B, Wilson JB, Campbell J (2002) The Sula Reef Complex, Norwegian shelf. Facies 47:179-200

Gherardi M, Giangrande A, Corriero G (2001) Epibiotic and endobiotic polychaetes of Geodia cydonium (Porifera, Demospongiae) from the Mediterranean Sea. Hydrobiol 443:87-101

Han M, Li Z, Zhang F (2013) The ammonia oxidizing and denitrifying prokaryotes associated with sponges from different sea areas. Microb Ecol 66:427-436

Henry L, Roberts JM (2007) Biodiversity and ecological composition of macrobenthos on cold-water coral mounds and adjacent offmound habitat in the bathyal Porcupine Seabight, NE Atlantic. Deep Sea Res I 54:654-672

Henry L-A, Davies AJ, Roberts JM (2010) Beta diversity of coldwater coral reef communities off western Scotland. Coral Reefs 29:427-436

Henry L-A, Moreno Navas J, Roberts JM (2013a) Multi-scale interactions between local hydrography, seabed topography, and community assembly on cold-water coral reefs. Biogeosciences 10:2737-2746

Henry L-A, Moreno Navas J, Hennige SJ, Wicks LC, Vad J, Roberts JM (2013b) Cold-water coral reef habitats benefit recreationally valuable sharks. Biol Conserv 161:67-70

Hewitt JE, Thrush SF, Dayton PD (2008) Habitat variation, species diversity and ecological functioning in a marine system. J Exp Mar Biol Ecol 366:116-122

Hoffmann F, Radax R, Woebken D, Holtappels M, Lavik G, Rapp HT, Schlappy M, Schleper C, Kuypers MMM (2009) Complex nitrogen cycling in the sponge Geodia barretti. Environ Microbiol 11:2228-2243

Hogg MM, Tendal OS, Conway KW, Pomponi SA, van Soest RWM, Gutt J, Krautter M, Roberts JM (2010) Deep-sea Sponge Grounds: Reservoirs of Biodiversity. UNEP-WCMC Biodiversity Series No. 32, UNEP-WCMC, Cambridge

Jensen A, Frederiksen R (1992) The fauna associated with the bankforming deepwater coral Lophelia pertusa (Scleractinaria) on the Faroe shelf. Sarsia 77:53-69

Kilgallen NM (2010) A new Antarctic species of Aristias Boeck (Crustacea, Amphipoda, Aristiidae), with remarks on the genus in Antarctica. Zootaxa 2426:43-53

Kiriakoulakis K, Freiwald A, Fisher E, Wolff GA (2007) Organic matter quality and supply to deep-water coral/mound systems of the NW European Continental Margin. Int J Earth Sci (Geol Rundsch) 96:159-170

Klitgaard AB (1995) The fauna associated with outer shelf and upper slope sponges (Porifera, Demospongiae) at the Faroe Islands, northeastern Atlantic. Sarsia 80:1-22 
Lenihan HS (1999) Physical-biological coupling on oyster reefs: How habitat structure influences individual performance. Ecol Monogr 69:251-275

Magnino G, Pronzato R, Sara A, Gaino E (1999a) Fauna associated with the horny sponge Anomoianthella lamella Pulitzer-Finali \& Pronzato, 1999 (Ianthellidae, Demospongiae) from Papua-New Guinea. Ital J Zool 66:175-181

Magnino G, Sara A, Lancioni T, Gaino E (1999b) Endobionts of the coral reef sponge Theonella swinhoei (Porifera, Demospongiae). Invertebr Biol 118:213-220

Maldonado M, Ribes M, van Duyl FC (2012) Nutrient fluxes through sponges: biology, budgets, and ecological implications. In: Becerro MA, Uriz MJ, Maldonado M, Turon X (eds) Advances in Sponge Science: Physiology, Chemical and Microbial Diversity, Biotechnology. Academic Press, Oxford, pp 113-182

McGuiness KA, Underwood AJ (1986) Habitat structure and the nature of communities on intertidal boulders. J Exp Mar Biol Ecol 104:97-123

McQuaid CD, Mostert BP (2010) The effects of within-shore water movement on growth of the intertidal mussel Perna perna: An experimental field test of bottom-up control at centimetre scales. J Exp Mar Biol Ecol 384:119-123

Mohn C, Rengstorf A, White M, Duineveld G, Mienis F, Soetaert K, Grehan A (2014) Linking benthic hydrodynamics and cold-water coral occurrences: A high-resolution model study at three cold-water coral provinces in the NE Atlantic. Prog Oceanogr 122:92-104

Montenegro-Gonzalez J, Acosta A (2010) Habitat preference of Zoantharia genera depends on host sponge morphology. Univ Sci 15:110-121

Moreno Navas J, Miller PL, Henry L-A, Hennige SJ, Roberts JM (2014) Ecohydrodynamics of cold-water coral reefs: a case study of the Mingulay Reef Complex (Western Scotland). PLoS One 9. doi:10.1371/journal.pone.0098218

Mueller CE, Larsson AI, Veuger B, Middelburg JJ, van Oevelen D (2014) Opportunistic feeding on various organic food sources by the cold-water coral Lophelia pertusa. Biogeosciences 11:123-133

Neves G, Omena E (2003) Influence of sponge morphology on the composition of the polychaete associated fauna from Rocas Atoll, northeast Brazil. Coral Reefs 22:123-129

Nielsen C, Riisgard HU (1998) Tentacle structure and filter-feeding in Crisia eburnea and other cyclostomatous bryozoans, with a review of upstream-collecting mechanisms. Mar Ecol Prog Ser 168:163-186

Oliver G, Allen JA (1980) The functional and adaptive morphology of the deep-sea species of the Arcacea (Mollusca: Bivalvia) from the Atlantic. Philos Trans R Soc Lond B 291:77-125

Padua A, Lanna E, Klautau M (2013) Macrofauna inhabiting the sponge Paraleucilla magna (Porifera: Calcarea) in Rio de Janeiro, Brazil. J Mar Biol Assoc UK 93:889-898

Peattie ME, Hoare R (1981) The sublittoral ecology of the Menai Strait: II. The sponge Halichondria panicea (Pallas) and its associated fauna. Estuar Coast Shelf Sci 13:621-635

Pielou EC (1975) Ecological diversity. Wiley, New York

Pile AJ, Young CM (2006) The natural diet of a hexactinellid sponge: benthic-pelagic coupling in a deep-sea microbial food web. Deep Sea Res I 53:1148-1156

Purser A, Orejas C, Gori A, Tong R, Unnithan V, Thomsen L (2013) Local variation in the distribution of benthic megafauna species associated with cold-water coral reefs on the Norwegian margin. Cont Shelf Res 54:37-51

R Core Team (2013) R: A language and environment for statistical computing. R Foundation for statistical computing, Vienna, Austria. http://www.R-project.org/

Raes M, Vanreusel A (2006) Microhabitat type determines the composition of nematode communities associated with sediment-clogged cold-water coral framework in the Porcupine Seabight (NE Atlantic). Deep Sea Res I 53:1880-1894

Ribeiro SM, Omena EP, Muricy G (2003) Macrofauna associated to Mycale microsigmatosa (Porifera, Demospongiae) in Rio de Janeiro State, SE Brazil. Estuar Coast Shelf Sci 57:951-959

Ribes M, Jimenez E, Yahel G, Lopez-Sendino P, Diez B, Massana R, Sharp JH, Coma R (2012) Functional convergence of microbes associated with temperate marine sponges. Environ Microbiol 14:1224-1239

Roberts JM and shipboard party (2013) Changing Oceans Expedition 2012. RRS James Cook 073 Cruise Report. Heriot-Watt University, Edinburgh

Roberts JM, Brown CJ, Long D, Bates CR (2005) Acoustic mapping using a multibeam echosounder reveals cold-water coral reefs and surrounding habitats. Coral Reefs 24:654-669

Roberts JM, Henry LA, Long D, Hartley JP (2008) Cold-water coral reef frameworks, megafaunal communities and evidence for coral carbonate mounds on the Hatton Bank, north east Atlantic. Facies 54:297-316

Roberts JM, Davies AJ, Henry L-A, Dodds LA, Duineveld GCA, Lavaleye MSS, Maier C, van Soest RWM, Bergman MJN, Huhnerbach V, Huvenne VAI, Sinclair DJ, Watmough T, Long D, Green SL, van Haren H (2009) Mingulay reef complex: an interdisciplinary study of cold-water coral habitat, hydrography and biodiversity. Mar Ecol Prog Ser 397:139-151

Ryland JS (2000) Reproduction in British zoanthids, and an unusual process in Parazoanthus anguicomus. J Mar Biol Assoc UK 80:943-944

Schaal G, Riera P, Leroux C (2011) Microscale variations of food web functioning within a rocky shore invertebrate community. Mar Biol 158:623-630

Schejter L, Chiesa IL, Doti BL, Bremec C (2012) Mycale (Aegogropila) magellanica (Porifera: Demospongiae) in the southwestern Atlantic Ocean: endobiotic fauna and new distributional information. Sci Mar 76:753-761

Skilleter GA, Russell BD, Degnan BM, Garson MJ (2005) Living in a potentially toxic environment: comparisons of endofauna in two congeneric sponges from the Great Barrier Reef. Mar Ecol Prog Ser 304:67-75

Stöhr S, Segonzac M (2005) Deep-sea ophiuroids (Echinodermata) from reducing and non-reducing environments in the North Atlantic Ocean. J Mar Biol Assoc UK 85:383-402

Stuart CT, Rex MA, Etter RJ (2003) Large-scale spatial and temporal patterns pf deep-sea benthic species diversity. In: Tyler PA (ed) Ecosystems of the Deep Oceans. Elsevier, Amsterdam, pp 295-312

Vad J (2013) Lophelia pertusa and associated species spatial distribution patterns and density at Mingulay Reef Complex. Ecole Normale Supérieure, Internship Report, p 21

Vader W (1983) Associations between amphipods (Crustacea: Amphipoda) and sea anemones (Anthozoa, Actiniaria). Australian Museum Memoir 18: Papers from the Conference on the Biology and Evolution of Crustacea. The Australian Museum, Sydney, pp 141-153

van Soest RWM, Lavaleye MSS (2005) Diversity and abundance of sponges in bathyal coral reefs of Rockall Bank, NE Atlantic, from boxcore samples. Mar Biol Res 1:338-349

van Soest RWM, de Voogd NJ (2013) Sponge species composition of north-east Atlantic cold-water coral reefs compared in a bathyal to inshore gradient. J Mar Biol Assoc UK 95:1461-1474

van Soest RWM, Cleary DFR, de Kluijver MJ, Lavaleye MSS, Maier C, van Duyl FC (2007) Sponge diversity and community composition in Irish bathyal coral reefs. Contrib Zool 76:121-142

van Weering TCE, de Haas H, de Stigter HC, Lykke-Andersen H, Kouvaev I (2003) Structure and development of giant carbonate mounds at the SW and SE Rockall Trough margins, NE Atlantic Ocean. Mar Geol 198:67-81 
Voultsiadou-Koukoura HE, Koukouras A, Eleftheriou A (1987) Macrofauna associated with the sponge Verongia aerophoba in the North Aegean Sea. Estuar Coast Shelf Sci 24:265-278

Westinga E, Hoetjes PC (1981) The intrasponge fauna of Spheciospongia vesparia (Porifera, Demospongiae) at Curacao and Bonaire. Mar Biol 62:139-150

Whitman ER, Reidenbach MA (2012) Benthic flow environments affect recruitment of Crassostrea virginica larvae to an intertidal oyster reef. Mar Ecol Prog Ser 463:177-191

Wienberg C, Beuck L, Heidkamp S, Hebbeln D, Freiwald A, Pfannkuche O, Monteys X (2008) Franken Mound: facies and biocoenoses on a newly-discovered "carbonate mound" on the western Rockall Bank, NE Atlantic. Facies 54:1-24
Witte U, Graf G (1996) Metabolism of deep-sea sponges in the Greenland-Norwegian Sea. J Exp Mar Biol Ecol 198:223-235

Witte U, Brattegard T, Graf G, Springer B (1997) Particle capture and deposition by deep-sea sponges from the Norwegian-Greenland Sea. Mar Ecol Prog Ser 154:241-252

Wulff J (2012) Ecological interactions and the distribution, abundance, and diversity of sponges. In: Becerro MA, Uriz MJ, Maldonado M, Turon X (eds) Advances in Sponge Science: Phylogeny, Systematics, Ecology. Academic Press, Oxford, pp 273-344

Yahel G, Whitney F, Reiswig HM, Eerkes-Medrano DI, Leys SP (2007) In situ feeding and metabolism of glass sponges (Hexactinellida, Porifera) studied in a deep temperate fjord with a remotely operated submersible. Limnol Oceanogr 52:428-440 